\title{
GASTRIC ACIDITY DURING THE FIRST YEAR OF LIFE
}

BY

\author{
R. A. MILlER, B.A., M.D., M.R.C.P.Ed.
}

(From the Department of Child Life and Health, The University of Edinburgh)

Prior to Cutter's investigations in 1938, the general belief was that there was little or no increase in gastric acidity during the first year of life. Hahn (1914) adopted this view after testing ninety-one specimens taken from thirtyseven infants before and after a milk feed. Hess (1913) and Griswold (1925) agreed, but added that the range of normal was extremely wide. In 1926, Wills and Paterson estimated the total acidity in eight infants after a milk feed; the maximum values for each individual lay between 49 and 70 c.c. $\mathrm{N} / 10 \mathrm{HCl}$ and the investigators were not convinced that age influenced the results. More recently, Klumpp and Neale (1930) using cream to stimulate the gastric secretion showed that there was a possible upward trend in acid concentration during the second six months of life. The results were not conclusive since only sixteen infants under one year were tested and of these only two were from seven to twelve months old. Steimann's (1936) results were also in agreement with those of previous investigators.

Marriott (1923) realized the difficulties of estimating gastric acidity in infancy by test feeds consisting of milk, for he states that not only is the buffer action of milk great, but the buffer constituents varied with the source of milk supply. Moreover, this phenomenon explains the occurrence of large amounts of combined acids with little or no free acid in many of the test-meal specimens obtained in the present investigations. Muller (1928) and Tomotake (1930) avoided the above difficulties by using either barley water or a solution of wheat flour and sugar, which have a feebler buffer action than milk. The latter author was thus able to demonstrate an increase in the total acidity and a fall in the $\mathrm{pH}$ of the gastric contents with advancing years, as has been stated by Babbott (1923) and five other authors quoted by him. Their conclusions, however, did not apply to infants under a year old. Babbott (1923) examined the gastric contents of thirty-nine infants one hour after they had taken a feed of dried skimmed milk with these results :-

TABLE 1

\begin{tabular}{|c|c|c|c|}
\hline \multirow{2}{*}{ AGE IN MONTHS } & \multirow{2}{*}{ NO. OF BABIES } & \multicolumn{2}{|c|}{$\mathrm{pH}$} \\
\hline & & RANGE & AVERAGE \\
\hline $\begin{array}{c}2-3 \\
4-6 \\
7-9 \\
12\end{array}$ & $\begin{array}{r}8 \\
19 \\
11 \\
1\end{array}$ & $\begin{array}{c}4 \cdot 6-5 \cdot 2 \\
3 \cdot 5-5 \cdot 5 \\
4 \cdot 0-5 \cdot 2 \\
3 \cdot 8\end{array}$ & $\begin{array}{l}4 \cdot 7 \\
4 \cdot 4 \\
4 \cdot 5 \\
3 \cdot 8\end{array}$ \\
\hline
\end{tabular}


In America, Cutter (1938) noted a rapid increase in gastric acidity during the first year of life (see table 2) and a much slower increase from the end of that period until the fourth year of life when the values almost reached adult standards, i.e. 53 c.c. average free acidity and 67 c.c. total acidity for the children as compared with 86 c.c. and 92.5 c.c. in adults after histamine stimulation (Chang, 1933). To demonstrate this Cutter injected histamine, 0.02 mgm. per $\mathrm{kgm}$. body weight hypodermically into infants starved for three to eight hours in whom the fasting juice had been removed. Four specimens of gastric contents were then taken off at ten minute intervals and analysed for free and total acidity.

TABLE 2

CUTTER'S SERIES

\begin{tabular}{c|c|c}
\hline & \multicolumn{2}{|c}{ MAXIMUM ACIDITY C.C. } \\
\cline { 2 - 3 } AGE (MONTHS) & F.A. & T.A. \\
\hline & 27 & 40 \\
$11 \frac{1}{2}$ & 80 & 105 \\
17 & 45 & 156 \\
18 & 63 & 74 \\
25 & 41 & 53 \\
\hline
\end{tabular}

\section{Present investigation}

Cutter's results have been confirmed without the use of histamine. The babies up to one month old were starved for eight hours, the rest obtained food three hours prior to investigation. A number six rubber catheter lubricated with glycerin or liquid paraffin was then passed into the stomach and its contents sucked out into a 10 c.c. syringe. Half an hour and one hour after a test-meal consisting of equal parts of milk and water, and amounting to 60 minims per pound body weight, had been given, a second and third sample of gastric contents were taken. All infants up to a month old, and two-thirds of those three and six months old received breast-milk and water, but older infants during the first year of life had cow's milk and water. The presence or absence of milk was noted, and the quantity of free and total acidity determined in the usual way. One technical difference was that the sodium hydroxide used for the titration was placed in a micro-burette in a dilution $\mathrm{N} / 70$.

Results. As stated in a preliminary report upon the behaviour of the gastric acidity during the first week of life (Miller, 1941), free hydrochloric acid was detected in all but twelve per cent. of the fifty healthy breast-fed infants whose gastric contents were examined daily during this period. Usually on the first or second day of life it was consistently greater in the fasting juice than after food. During the latter half of the week even after a meal of milk and water free acid was almost always absent. The total acidity ranged from 5 to 100 c.c. $\mathrm{N} / 10 \mathrm{HCl}$ per 100 c.c. gastric contents, and the highest values were recorded during the first two days of life, almost always in the fasting specimens. For the remaining part of the week the variation in the amounts of total acidity throughout the test-meal was small, and by the seventh day of life it was 
remarkable how in almost every case the half-hour and one-hour specimen after a feed contained more acid than in the sample taken while fasting. This transition in the type of secretory response to a meal is represented in chart I.

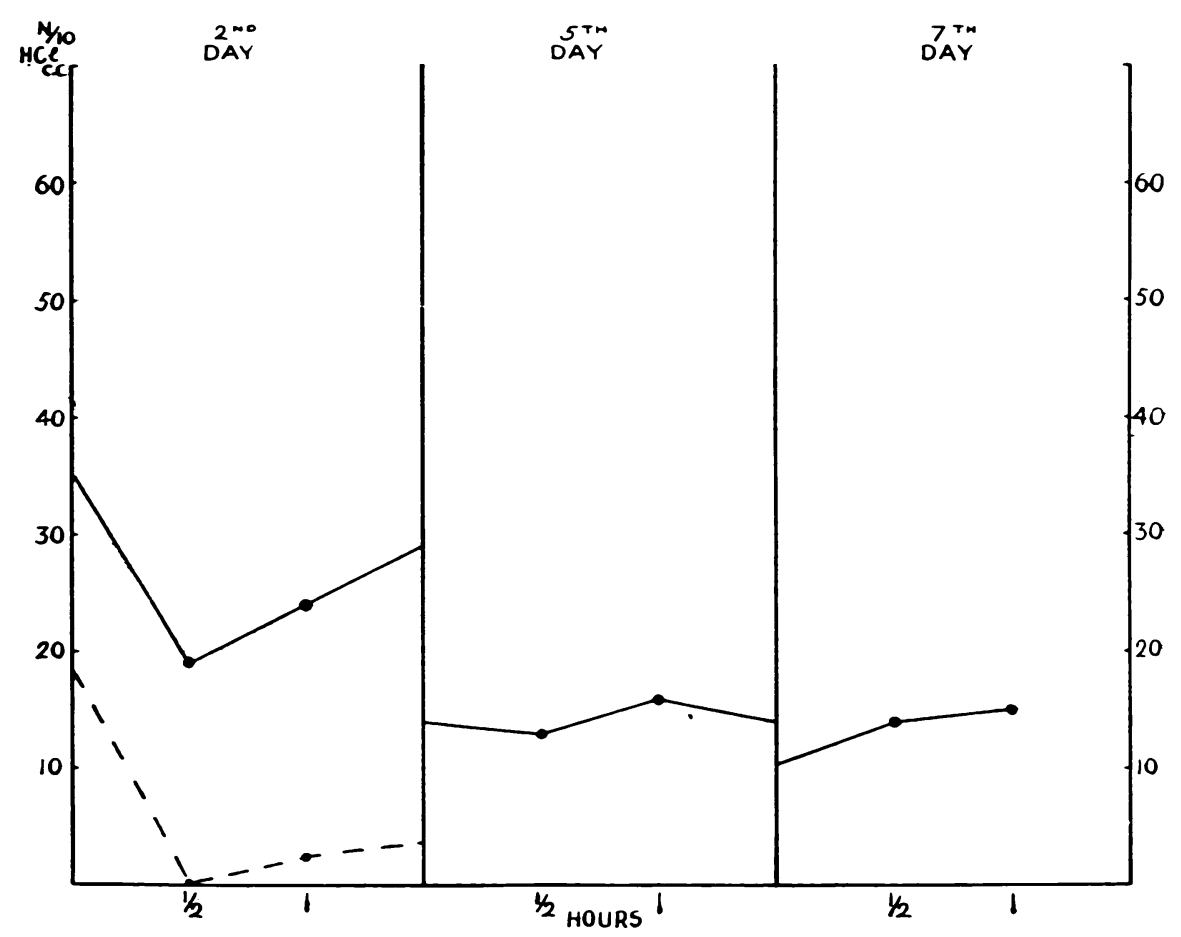

ChART I.-Continuous line indicates average total acidity. Interrupted line indicates average free acidity.

In healthy breast-fed infants two weeks old, the behaviour of the gastric secretion was found to be similar to that at the end of the first week of life. Free acid was only detected once out of sixty test-meals performed at this age. The combined acid generally fluctuated in any given individual less than 10 c.c. and rarely more than 20 c.c. The average figures given in chart II are slightly higher than those for the previous week.

When the infants were three weeks old hydrochloric acid definitely reappeared ; it was found in three out of twenty-one fasting juices and in half the specimens taken one hour after a meal. The average amount of combined acid was also higher than those for the preceding week (see chart II). After a more detailed study of the results it was found that the maximum acidity followed the giving of food except for four out of twenty-one cases.

A corresponding number of healthy breast-fed babies were tested when they were four weeks old. Free acid was present in the same percentage of specimens as in the last group, while the average figures for total acidity were all elevated (see chart II). It was strange that the values for twenty premature infants of this age were greater : 
GASTRIC ACIDITY DURING THE FIRST YEAR OF LIFE 201

TABLE 3

\begin{tabular}{|c|c|c|c|c|}
\hline & & & MATURE INFANT C.C. & PREMATURE INFANT C.C. \\
\hline Fasting juice $\quad$. & .. & $\begin{array}{l}\text { F.A. } \\
\text { T.A. }\end{array}$ & $\begin{array}{r}3 \\
23\end{array}$ & $\begin{array}{r}3 \\
25\end{array}$ \\
\hline Half hour p.c. .. & .. & $\begin{array}{l}\text { F.A. } \\
\text { T.A. }\end{array}$ & $21^{0.5}$ & 33 \\
\hline One hour p.c. .. & .. & $\begin{array}{l}\text { F.A. } \\
\text { T.A. }\end{array}$ & 25 & $\begin{array}{l}15 \\
31\end{array}$ \\
\hline
\end{tabular}

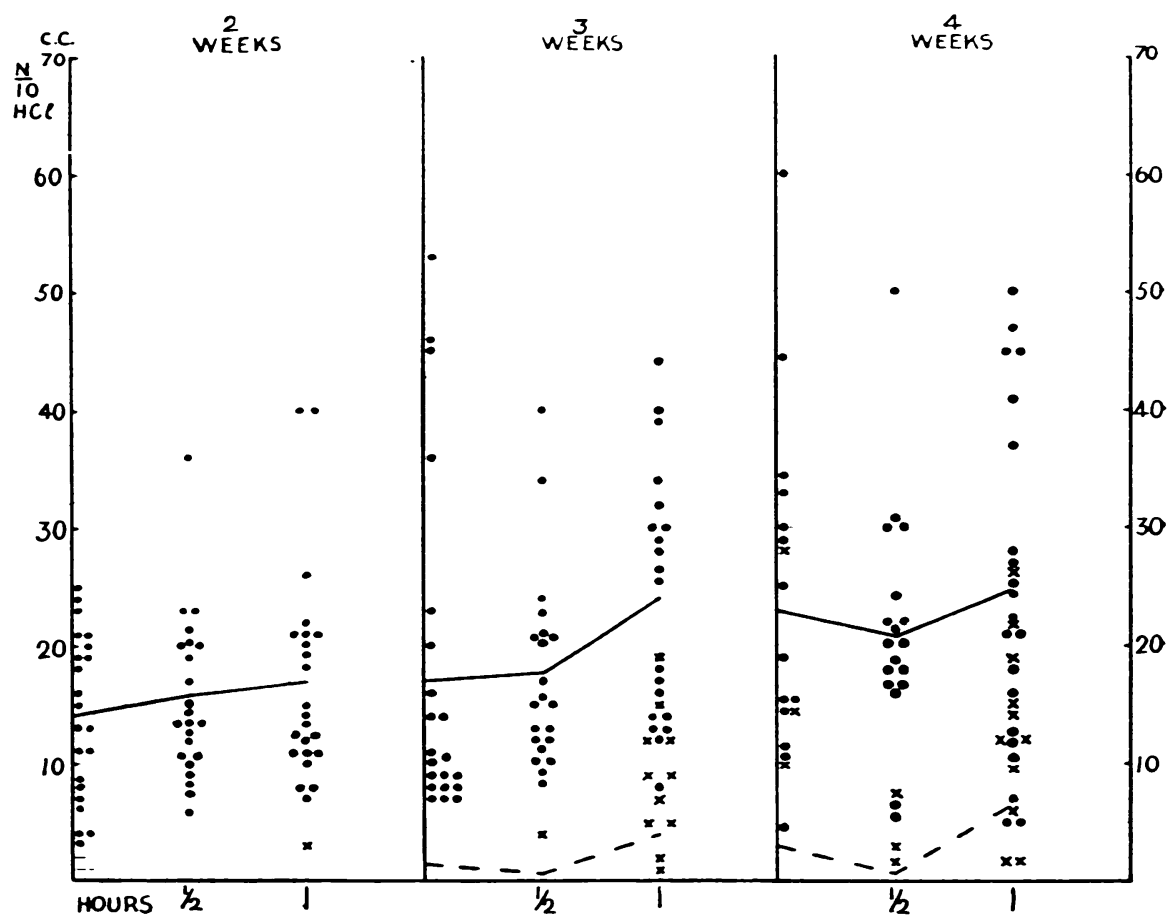

CHART II.-Dot indicates individual estimations of total acidity. Cross indicates individual estimations of free acidity. Continuous line represents average total acidity. Interrupted line represents average free acidity.

It is difficult to explain this finding on physiological grounds as the infants were all healthy and given breast milk from birth. The premature infants, however, had never been discharged from hospital whereas the mature infants went home with their respective mothers ten days after delivery.

In twenty infants, twelve weeks old, free acid was present in seventy-six per cent. It definitely occurred more frequently after they had been fed, whether the half-hour or hour specimen was examined. The striking change in the behaviour of the total acidity was not only the raised average values but also the growing range between maximum and minimum figures during the test, which amounted to 80 c.c. and 7 c.c. respectively, the average being 34 c.c. (chart III). During the twenty-fourth week and the twelfth month of life 


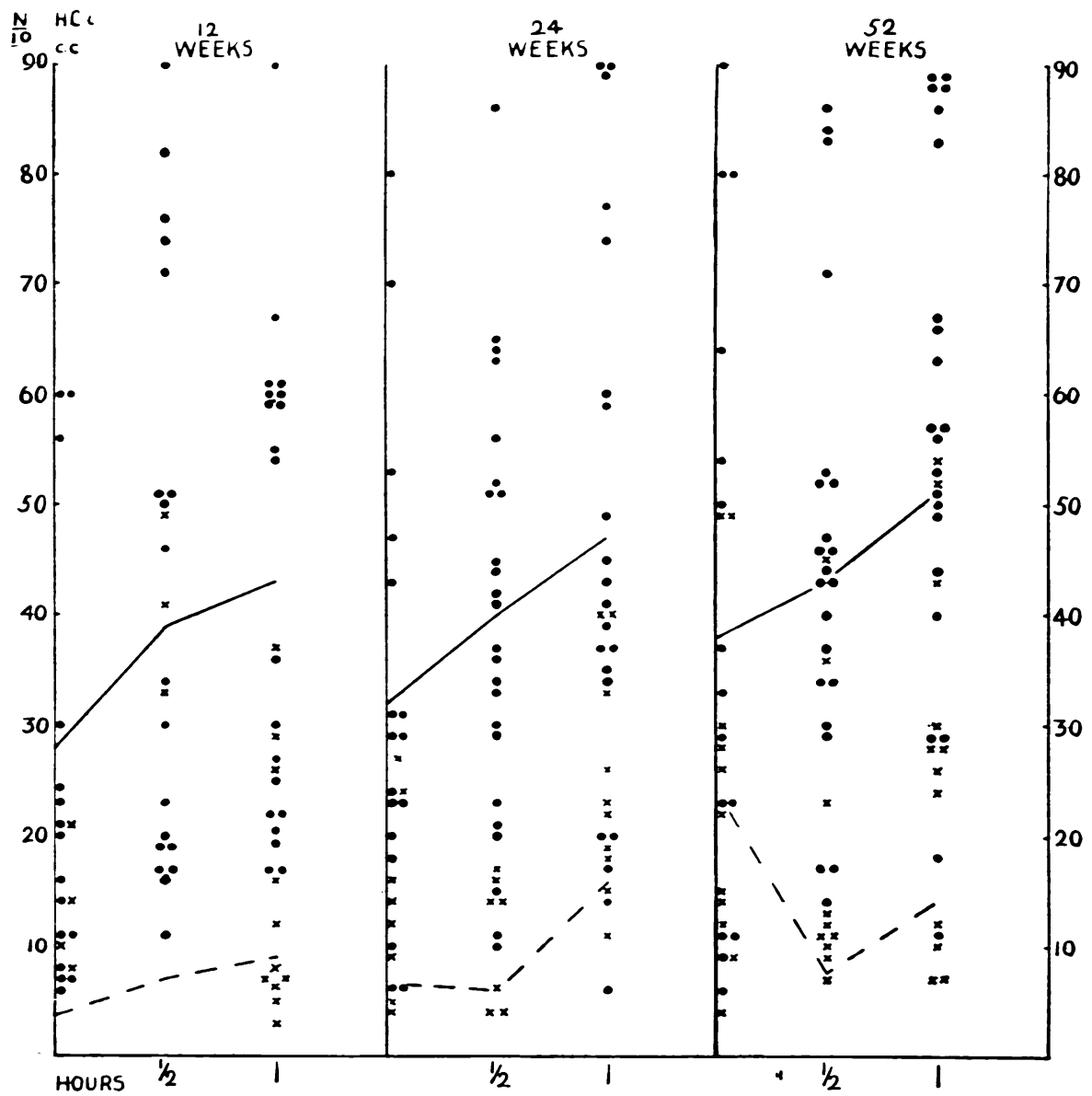

ChART III.-Dot indicates individual estimations of total acidity. Cross indicates individual estimations of free acidity. Continuous line represents average total acidity. Interrupted line represents average free acidity.

little alteration in gastric secretion was found, apart from the tendency of the concentration of acid to rise. The salient feature was the great range of normal for free and total acidity ; even throughout the tests the fluctuation in degree of total acid was generally great and averaged 28 c.c. and 40 c.c. for each age group. The highest values were recorded in 73 per cent. to 82 per cent. of cases one hour after a feed of milk and water (chart III), and are equivalent to adult figures following a meal of either cow's milk or human milk (Hawk and Bergeim, 1938).

COMPARISON OF FREE AND TOTAL ACIDITY. The difference between these two values is approximately twenty units in an adult. Similar values in some fasting juices were obtained during the first year of life, but in the majority of samples, taken either before or after the test meal, this figure was exceeded.

This is explained by the presence of relatively concentrated and potent buffer substances in the milk and these neutralized the free acid, a fact 
GASTRIC ACIDITY DURING THE FIRST YEAR OF LIFE 203

vividly demonstrated by examining gastric residue of forty-four infants which contained either milk or gruel three hours after a feed. In all but one of these specimens the values of total acidity were higher than the average for its age group, while the free acid was slightly more, or less, than the average.

TABLE 4

DIFFERENCE BETWEEN FREE AND TOTAL ACIDITY

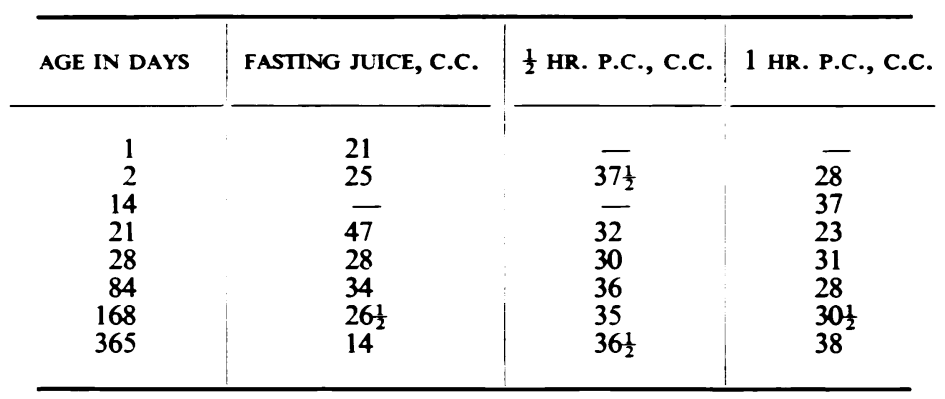

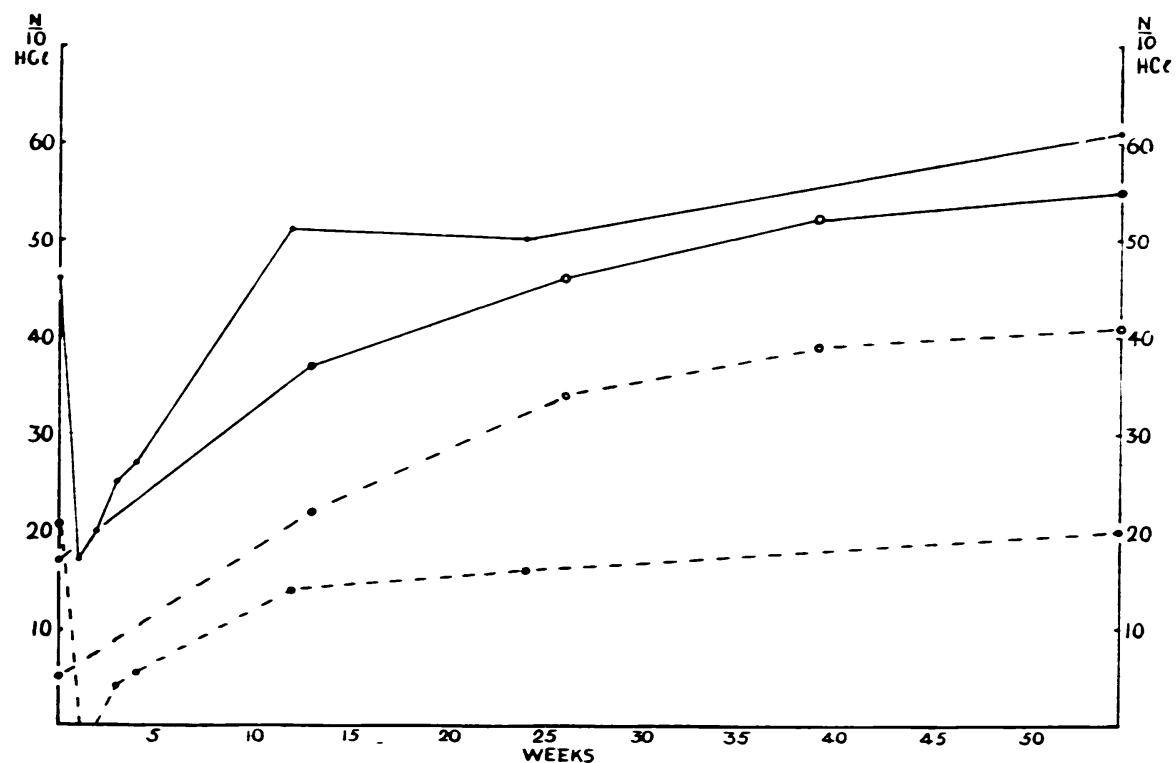

ChaRt IV.-Dots signify values obtained in present series of cases. Circles signify values obtained by Cutter (1938). Continuous line represents average total acidity. Interrupted line represents averege free acidity.

Table 5 also shows that at least fifty per cent. infants aged one to twelve months require more than three hours for their stomachs to empty after a milk feed, bread and milk or gruel and milk. Therefore, it is preferable to starve infants for eight hours before performing such a test.

ACHLORHYDRIA. Oliver and Wilkinson (1933), in the most recent and extensive review on achlorhydria in both adults and children, did not believe 
TABLE 5

\begin{tabular}{|c|c|c|c|c|c|c|}
\hline \multirow[b]{2}{*}{$\begin{array}{l}\text { AGE GROUP IN } \\
\text { WEEKS }\end{array}$} & \multicolumn{3}{|c|}{ NORMAL FASTING JUICE } & \multicolumn{3}{|c|}{ CONTAMINATED FASTING JUICE } \\
\hline & No. CASES & F.A., C.C. & T.A., C.C. & NO. CASES & F.A., C.C. & T.A., C.C. \\
\hline $\begin{array}{r}3 \\
4 \\
12 \\
24 \\
52\end{array}$ & $\begin{array}{l}20 \\
14 \\
17 \\
18 \\
15\end{array}$ & $\begin{array}{c}1 \frac{1}{2} \\
3 \\
4 \\
5 \frac{1}{2} \\
24\end{array}$ & $\begin{array}{l}17 \\
23 \\
28 \\
32 \\
38\end{array}$ & $\begin{array}{r}3 \\
8 \\
15 \\
10 \\
8\end{array}$ & $\begin{array}{c}6 \\
2 \frac{1}{2} \\
7 \\
1 \\
23 \frac{1}{2}\end{array}$ & $\begin{array}{l}59 \\
61 \\
86 \\
86 \frac{1}{2} \\
88\end{array}$ \\
\hline
\end{tabular}

any conclusion could be drawn as to the state of affairs in infants owing to the lack of adequate statistics. In the newborn infant, most investigators (Tangl, 1906; Hess, 1913; Pollitzer, 1921; Griswold, 1925; and Faber, 1927) are of the opinion that anacidity is non-existent, a view not shared by Miller (1941) who failed to find free hydrochloric acid in the gastric residue of six out of fifty normal infants who were examined daily for the first ten days of life. Moreover, one of these babies, No. 3874, exhibited achylia gastrica two years later, even after the administration of histamine. This baby, No. 3874, was born on March 30, 1940. His birth weight was $6 \mathrm{lb}$. $11 \mathrm{oz}$. He was born spontaneously and normally. The infant grew up to be a strong healthy child and when two years old (March 23, 1942), his gastric content was examined three hours after a meal of bread and milk. The sample contained some bread and its total acidity amounted to 23 c.c. $\mathrm{N} / 10 \mathrm{HCl}$. per 100 c.c. gastric contents, free acids being absent. The infant was then given histamine $0.2 \mathrm{mgm}$. hypodermically. Two additional samples were then obtained from the stomach at twenty minute intervals. The last two samples still contained remnants of the bread and milk feed but no further rise in total acidity was recorded, 14 c.c. and 26 c.c. being present. Free hydrochloric acid was still absent. Incidentally it was noticed that cutaneous hyperaemia of head and neck occurred about ten minutes after the histamine injection, thus showing the efficacy of the drug.

The incidence of apparent achylia gastrica following the standard test-meal of milk and water throughout the first year of life is variable; it was recorded in a hundred per cent. of infants two weeks old, forty and thirty-five per cent. when three and four weeks old respectively, and only half the latter figure at three, six and twelve months old. From this time onwards until adolescence there is a small but progressive reduction of achlorhydria with Ewald or modified Ewald test meals (see table 6). The occurrence of true achylia is probably much less, for Cutter (1938) only noted four cases out of ten healthy infants in the neonatal period following an injection of histamine, 0.02 mgm. per kgm. body weight. Thereafter he did not record another case in a series of thirty-five infants in the first year of life. In this last group Lehmann (1935) tested thirty infants, one of which was twelve months old and it exhibited achylia after $0.2 \mathrm{mgm}$. histamine. No older infant or child has been shown to have this deficiency after histamine administration as judged by investigations upon twenty-one infants aged one to four years (Cutter, 1938) and sixty between six months and twelve years of age (Ogilvie, 1934). Therefore, it may be concluded that the incidence of both anacidity and hypoacidity diminishes rapidly during the first year of life. In older infants or children anacidity is probably exceptional, whereas the incidence of hypochlorhydria shows a slow but definite reduction with age. According to the literature changes of this 
nature during the first to twelfth year of life are associated not only with a linear increase in concentration of gastric acidity (Vanzant, 1932; Ogilvie, 1934) but also an increase in volume of the gastric juice (Neale, 1930). These factors are also probably responsible for the changes in gastric acidity during the first year of life.

TABLE 6

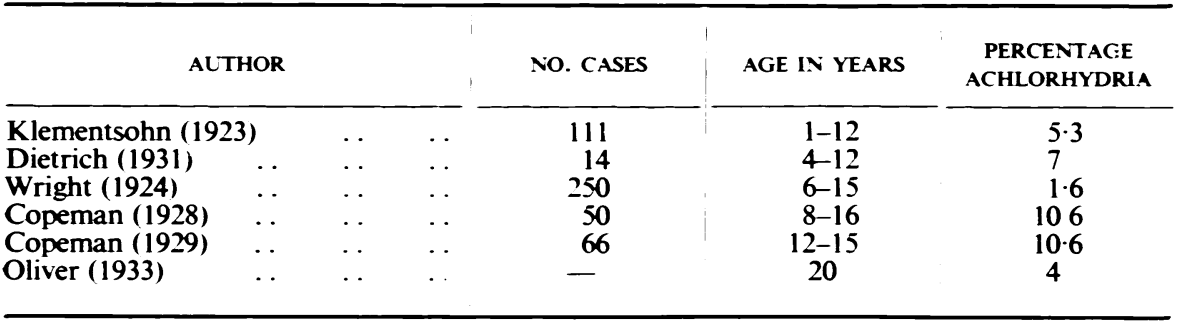

This gastric anomaly has been explained by several theories which include gastritis, neurogenic or constitutional disorders. Of congenital abnormalities, persistence of the infantile glandular state and an inborn deficiency in the functional capacity of the gland are most important in the production of achylia gastrica in infancy and childhood. For example the subnormal structural development of the acid secretory elements in premature infants has been shown to accompany the increase in frequency of achlorhydria.

In addition histological examination of mature infants' stomachs has shown that they may also have a primitive gastric mucosa, of a type usually found in newborn infants weighing three pounds (Scott, 1925; Miller, 1941). Bauer (1921) is also a strong supporter of this theory. The opposing view that achlorhydria is an inborn deficiency in the functional capacity of the gland which has a normal structure is held by Hurst (1923), who noted that pathological changes in the stomach in achylia are so slight and patchy that there can be no question of achylia arising from actual destruction of the secretory cells. This conclusion is supported by the present observation that newborn babies as a rule secrete free hydrochloric acid. sometimes in high concentration, and yet at a week old fail to do so. Furthermore it has also been shown that there is a diminution in the incidence of hypochlorhydria up to the age of twenty.

RELATIONSHIP OF ANACIDITY TO DISEASE. Ill health, malnutrition, allergic disease, as well as certain skin diseases and vomiting, may result in a reduction in gastric acidity. It is questionable whether eczema should be included, for Cutter (1938) found high concentrations of free acid in the stomachs of five infants suffering from this condition after they had received histamine. In the present investigations seven babies, less than twenty-eight weeks old, had localized or generalized eczema and yet no more than a doubtful hypochlorhydria existed (table 7). This suggests that treatment of such cases with lactic acid milk benefits them not by making good the deficient secretion but in a manner comparable to altering the diet of a person suffering from epilepsy or asthma.

Persistent vomiting in infancy, from various causes, results in a more acid 
gastric secretion (Wills and Paterson, 1926; Stiemann, 1936), but with pyloric stenosis, (Salmi, 1937), hypochlorhydria tends to develop.

TABLE 7

GASTRIC ACIDITY OF BABIES WITH ECZEMA

\begin{tabular}{|c|c|c|c|c|c|c|c|c|}
\hline \multirow{2}{*}{$\begin{array}{c}\text { AGE } \\
\text { (WEEKS) }\end{array}$} & \multirow{2}{*}{$\begin{array}{l}\text { DURATION } \\
\text { OF ECZEMA } \\
\text { (WEEKS) }\end{array}$} & \multirow[t]{2}{*}{ SITE OF LESION } & \multicolumn{2}{|c|}{$\begin{array}{l}\text { FASTING JUICE } \\
\text { C.C. }\end{array}$} & \multicolumn{2}{|c|}{$\begin{array}{l}\frac{1}{2} \text { HR. P.C. } \\
\text { C.C. }\end{array}$} & \multicolumn{2}{|c|}{$\begin{array}{l}1 \text { HR. P.C. } \\
\text { C.C. }\end{array}$} \\
\hline & & & F.A. & T.A. & F.A. & T.A. & F.A. & T.A. \\
\hline $\begin{array}{r}9 \\
14 \\
22 \\
10 \\
7 \\
31 \\
27\end{array}$ & $\begin{array}{r}4 \\
2 \\
2 \\
2 \\
2 \\
1 \\
14\end{array}$ & $\begin{array}{l}\text { General } \\
\text { Scalp } \\
\text { Head } \\
\text { Face and trunk } \\
\text { Face } \\
\text { Face } \\
\text { Head }\end{array}$ & $\begin{array}{l}0 \\
0 \\
0 \\
4 \\
0 \\
0 \\
0\end{array}$ & $\begin{array}{r}44 \\
9 \\
6 \\
46 \\
27 \\
6 \\
94\end{array}$ & $\begin{array}{l}0 \\
0 \\
0 \\
0 \\
0 \\
0 \\
6\end{array}$ & $\begin{array}{l}33 \\
27 \\
30 \\
31 \\
21 \\
24 \\
86\end{array}$ & $\begin{array}{r}0 \\
17 \\
0 \\
7 \\
0 \\
2 \\
20\end{array}$ & $\begin{array}{l}27 \\
43 \\
40 \\
30 \\
25 \\
37 \\
70\end{array}$ \\
\hline
\end{tabular}

Additional facts regarding gastric function before and after the development of this disease can be learnt from the three case records :-

BABY NO. 6202, was born on January 18,1941 , weighing $7 \mathrm{lb} .10 \mathrm{oz}$. He was the first child of a mother who had bilateral pulmonary tuberculosis and was delivered with forceps after $50 \frac{1}{2}$ hours labour. The baby's general condition at birth was good and he was fed on cow's milk and water. At two weeks old he was $5 \mathrm{oz}$. below birth weight and his progress had been normal apart from vomiting twice when twelve days old and once the next day. During the third week of life he never vomited his feeds and was discharged from hospital at the end of that week weighing $\frac{3}{4} \mathrm{oz}$. more than he did at birth. Two standard test-meals were given to this infant, one when two weeks old and the other when three weeks old. The quantity of the fasting juice did not exceed 0.2 c.c. and contained no milk. One hour after the testmeal there was only a trace of milk curd left in the stomach. The quantity of acid present showed no deviation from the normal.

The baby returned to hospital eleven days later (February 19, 1941) because of vomiting. He had lost $12 \mathrm{oz}$. owing to pyloric stenosis. On the second, third and fourth day after re-admission to hospital the gastric residue measured 6-20 c.c. and contained milk eight hours after a feed. The total acidity was 23-100 c.c. while on only one occasion free acid, 3 c.c., was present. Ultimately, the infant was treated surgically and the diagnosis confirmed.

\begin{tabular}{|c|c|c|c|c|c|}
\hline & & \multicolumn{2}{|c|}{ AT 2 WEEKS C.C. } & \multicolumn{2}{|c|}{ AT 3 WEEKS C.C. } \\
\hline & & F.A. & T.A. & F.A. & T.A. \\
\hline $\begin{array}{l}\text { Fasting juice } \\
\text { Half hour p.c. } \\
\text { One hour p.c. }\end{array}$ & $\begin{array}{l}\ldots \\
\cdots \\
\ldots\end{array}$ & $\begin{array}{l}\mathbf{0} \\
\mathbf{0} \\
\mathbf{0}\end{array}$ & $\begin{array}{r}8 \\
13 \\
13\end{array}$ & $\begin{array}{l}0 \\
0 \\
0\end{array}$ & $\begin{array}{l}23 \\
17 \\
12\end{array}$ \\
\hline
\end{tabular}

F.A. indicates free acidity in c.c. $\mathrm{N} / 10 \mathrm{HCL}$ per 100 c.c. gastric contents.

T.A. indicates total acidity in c.c. N/10 HCL per 100 c.c. gastric contents.

BABY NO. 5756. Born on December 29, 1940. Weighed $6 \mathrm{lb} .13 \mathrm{oz}$. He was the first child of a healthy mother aged thirty-eight who was delivered by 
Caesarian section. At first he progressed normally but slowly, his weight being $6 \mathrm{lb}$. $6 \mathrm{oz}$. when two weeks old. Two days later vomiting started and persisted to the end of the third week of life when his weight had fallen to $6 \mathrm{lb}$. $\frac{1}{2} \mathrm{oz}$. and the diagnosis of pyloric stenosis was established. The baby was therefore treated surgically and the diagnosis confirmed. A standard testmeal performed at the age of two weeks, i.e. prior to vomiting, did not suggest gastric stasis as the volume of the fasting juice was only 2 c.c. and contained no milk after fasting for eight hours. There were 6 c.c. combined acid in the fasting specimen and 20 and 13 c.c. in the half hour and one hour specimens respectively. After two days of vomiting the volume of the fasting juice after eight hours of starvation was abnormal; it measured at least 10 c.c. and consisted chiefly of milk. There were 30 c.c. free acid and 63 c.c. of total acidity.

BABY No. 6893 was a normal female infant weighing $7 \mathrm{lb} .10 \frac{1}{2} \mathrm{oz}$. at birth (April 21, 1941) who exhibited pyloric stenosis during the third week of life. When two weeks old she was 7 oz. below birth weight but had not vomited. On the sixteenth day of life vomiting began and the infant's weight fell each day until she only weighed $6 \mathrm{lb} .3 \mathrm{oz}$. at three weeks old. Three days following the onset of vomiting (May 9, 1941) the infant was given the standard testmeal of milk and water after fasting for eight hours; the fasting juice contained a large amount of milk and its volume was 30 c.c. Specimens removed half and one hour after the test feed were easily obtained and milk was present in both. At no time was free hydrochloric acid found in the stomach contents but the total acidity in each specimen measured 103 c.c., 31 c.c. and 38 c.c. respectively. The infant was operated upon two weeks after the symptoms of the disease appeared and the diagnosis of pyloric stenosis was substantiated.

In pyloric stenosis gastric secretion prior to the onset of symptoms is normal in quantity and acidity, but as soon as vomiting occurs there is gastric stasis, the gastric residue measuring over 4 c.c. and containing milk eight hours after a feed. The free and total acidity is raised in these specimens but later achlorhydria develops. The combined acids, however, remain persistently elevated. Such findings are not pathognomonic of the disease, and have been recorded in severe cases of idiopathic diarrhoea and vomiting.

Motility OF THE STOMACH. According to Davidsohn (1921) and Szasz (1930) the motility of the stomach in childhood varies directly with gastric acidity and muscular tonicity of the gastro-intestinal tract. This may explain the diminishing emptying time of the stomach throughout the first year of life, as illustrated by the following table.

TABle 8

\begin{tabular}{c|c|l}
\hline $\begin{array}{c}\text { AGE IN } \\
\text { WEEKS }\end{array}$ & NO. CASES & \multicolumn{1}{|c}{$\begin{array}{c}\text { MILK IN STOMACH } \\
1 \text { HOUR P.C. }\end{array}$} \\
\hline 1 & 20 & $\begin{array}{l}\text { Generally }++ \\
\text { Trace or }+\end{array}$ \\
2 & 23 & Trace or t \\
3 & 21 & Generally absent \\
4 & 21 & Absent in 50 per cent. cases \\
12 & 20 & Absent in 40 per cent. Trace in 43 per cent. \\
24 & 21 & Absent in 41 per cent. Trace in 14 per cent. \\
52 & 22 & \\
\hline
\end{tabular}


The stomach in infancy almost certainly requires more than one hour to empty (Moritz, 1933) for a normal feed is generally more voluminous and less diluted with water than the one used for the present observations. For example forty-one out of one hundred and seven infants one to twelve months old require more than three hours for their stomachs to empty after a milk feed, bread and milk or gruel and milk. When interpreting such results the psychological disturbance produced by performing the test must not be neglected for it was noticeable that six-months old infants and more particularly those of one year old had a greater distaste for milk feeds and the passage of the catheter into their stomachs than younger infants.

\section{Conclusion}

Gastric acidity during the first year of life shows a rapid increase in concentration (chart IV) with a probable increase in volume. At the end of this period the reaction of the stomach to a test-meal of milk closely resembles that of an adult, for the maximum and average values are almost identical in the two age groups. Accompanying the development of the digestive powers of the infant there is a diminution in the number of achlorhydric infants. The change applies to both true and false varieties of achylia, which is almost always transitory and not permanent; a fact which corresponds to the modern conception of gastric secretory function in adults (Chang, 1933; Morrison, 1938).

The behaviour of gastric secretion in infantile eczema and pyloric stenosis has also been studied. The results show that any disturbance that may be observed in these diseases is certainly not primary but secondary.

The present study on gastric acidity has been carried out under the auspices of the Kirk Duncanson Fellowship for Medical Research, The Royal College of Physicians of Edinburgh. Thanks are due to Professor Charles MacNeil and the obstetricians in charge of the wards of The Simpson Maternity Pavilion, The Royal Infirmary, Edinburgh, for the facilities to carry out the work. Not only has Professor MacNeil helped in this way but also by his constant interest and advice. Thanks are also due to Sister Taylor and Sister Stenhouse for their co-operation and technical assistance in performing the test-meals.

\section{REFERENCES}

Babbott, F. L., et al. (1923). Amer. J. Dis. Child., 26, 475.

Bauer, J. (1921). Die konstitutionelle Disposition zu inneren Krankheiten, Berlin, 421.

Chang, H. (1933). J. clin. Invest., 12, 155.

Copeman, W. S. C., and Hill, N. G. (1928). Quart. J. Med., 22, 33.

- (1929). Lancet, 1, 718.

Cutter, R. D. (1938). J. Paediat., 12, 1.

Davidsohn, H. (1921). Arch. Kinderheilk., 69, 142.

Dietrich, H., and Shelby, D. C. (1931). Amer. J. Dis. Child., 41, 1086.

Faber, K. (1927). Lancet, 2, 901.

Griswold, C., and Shohl, A. T. (1925). Amer. J. Dis. Child., 30, 541.

Hahn, M. (1914). Ibid., 7, 305.

Hawk, P. B., and Bergeim, O. (1938). Practical physiological chemistry, Lond., 11th ed., p. 284.

Hess, A. F. (1913). Amer. J. Dis. Child., 6, 264.

Hurst, A. F. (1923). Lancet, 1, 111. 


\section{GASTRIC ACIDITY DURING THE FIRST YEAR OF LIFE 209}

Klementsohn, E. (1923). Acta paediatr., Stockh., 3, 136.

Klumpp, T. G., and Neale, A. V. (1930). Amer. J. Dis. Child., 40, 1213.

Lehmann, H. (1935). Ber. ges. Physiol., 87, 347.

Marriott, W. McK., and Davidson, L. T. (1923). Amer. J. Dis. Child., 26, 542.

Miller, R. A. (1941). Arch. Dis. Childh., 16, 22, and 113.

Moritz, D. von. (1933). Arch. Kinderheilk., 99, 23.

Morrison, S. (1938). Amer. J. Digest. Dis., 5, 617.

Muller, J. (1928). Arch. Kinderheilk., 84, 250.

Neale, A. V. (1930). Arch. Dis. Childh., 5, 137.

Ogilvie, J. W. (1934). Ibid., 9, 327.

Oliver, T. H., and Wilkinson, J. J. (1933). Quart. J. Med., 26, 431.

Pollitzer, R. (1921). Pediatria, 29, 253.

Salmi, T. (1937). Acta paediatr., Stockh., 21, 362.

Scott, G. H. (1925). Amer. J. Dis. Child., 30, 145.

Steimann, W. (1936). Mschr. Kinderheilk., 65, 264.

Szasz, A. von S. (1930). Ibid., 47, 55.

Tangl, F. (1906). Pflüg. Arch. ges. Physiol., 115, 64.

Tomotake, I. (1930). Jb. Kinderheilk., 129, 312.

Vanzant, F. R., et al. (1932). Arch. intern., Med., 49, 345.

Wills, L., and Paterson, D. (1926). Arch. Dis. Childh., 1, 232.

Wright, C. B. (1924). Arch. intern. Med., 33, 435. 